\title{
Possibilities of Entrepreneur Potential Development of Yamal-Nenets District
}

\author{
Elena Chizhevskaya: \\ Department of Management in the fuel and energy sector \\ Tyumen Industrial University \\ Tyumen, Russia \\ chizel76@yandex.ru
}

\author{
Marina B. Balikaeva: \\ Department of Cross-cultural Communication \\ Tyumen Industrial University \\ Tyumen, Russia \\ marinabalikaeva@list.ru
}

\begin{abstract}
The entrepreneurship development in modern Russia is associated with a number of features and conditions, including the territorial location factors and the region social and economic development level. On the other hand, the small and medium business is the main source of revenues to budgets. It provides employment for the population and affects the population life quality. The article presents an overview of the developing entrepreneurial structures possibilities of a mono-raw territory. The authors identified the strengths and weaknesses of the Yamal-Nenets district economy, the opportunities and threats to its development. The article pays special attention to the influence of the fuel and energy complex on the development possibilities of the territory under consideration.
\end{abstract}

Keywords-entrepreneurship; small business; development strategy; social and economic development of the region.

\section{INTRODUCTION}

Entrepreneurship is a driving factor in the development of the Russian economy. According to the message of the President of the Russian Federation, it is necessary to create conditions for the most favorable conditions for the development of entrepreneurial structures. They include financial support measures, organizational mechanisms, an assistance in the business development and an access to international markets. At the same time, the opportunities for the small and medium-sized businesses development are different in regions of Russia due to a number of circumstances. This article is devoted to the study of the example of the Yamal-Nenets Autonomous District.

\section{PROBLEM STATEMENT}

The territorial development strategy aims to raise the level and quality of the population life and well-being. This aim can be achieved through the most promising sectors management development and employment of the population. The economy of the Yamal-Nenets Autonomous District has a mono-raw specialization and limited opportunities for the entrepreneurial structures development [1]. This is due to complex natural and climatic conditions, territorial remoteness, disunity, and low population density. In addition, the traditional economic sectors of the district (oil, gas and gas condensate extraction) require large capital investments and represent large vertically integrated companies. Their activities have a connection with the use of the largest resources located in the territory of YamalNenets Autonomous District. For the development of small and medium-sized businesses, it is advisable in the field of infrastructure facilities that support the fuel and energy sector [2]. These areas are the most important resources for realizing the entrepreneurial potential of the district.

Thus, the state of the oil and gas sector has the strongest impact on the results of the district's social and economic development [3]. This dependence is an indicator of weak economic diversification, which carries high risks.

The evaluation of activities indicates a narrow specialization and concentration on hydrocarbon production in the fuel and energy sector of the district. This means that the economic situation will become worse with the fall in production volumes. In this connection, it is advisable to consider the possibilities of producing the final product from the extracted raw materials. It is necessary to create oil and gas refineries. Prerequisites and all resources are available for it in the territory.

The significant negative impact on the image and income in budgets of different levels had a situation in reindeer husbandry. This is a striking fact of the negative influence of one-sided industrialization on the living conditions of the north indigenous peoples. In this regard, an area of business structures development is a creation of enterprises whose activities are aimed at implementing environmental projects (land reclamation, waste recycling, construction and commissioning of treatment facilities, etc.)

The high rate of district population aging is another distinguishing feature of this district. The high rates of the population aging will lead to a significant increase of the population proportion of the over working age. It will lead to the impossibility of financing from the district budget of the district pensioners [4].

The energy deficit of the Yamal-Nenets Autonomous District also increases substantially the risks of the social and economic development in the future. Low transport development of the territory hinders the resources development. The weak energy base and the energy development determined the region energy deficit. 
There is the large difference in social and economic development between the oil and gas and rural districts [5]. Agricultural production in rural has the low economic efficiency, primarily because the territory belongs to the Far North regions and their agriculture is costly. The presence of disproportions in the social and economic development of municipalities has a deterrent effect on the autonomous region development because it leads to a redistribution of budget funds in the direction of increasing current expenditure[6].

The most important competitive advantage of the Yamal-Nenets Autonomous District is one of the world's largest pipeline systems for the transportation of natural gas. The existing gas transportation infrastructure allows planning the commissioning of new gas fields [7]. Their products will replace the fields gas located at the stage of falling production. The system of the main pipeline transport of the Yamal-Nenets Autonomous District allows pumping almost 600 billion cubic meters of natural gas outside the Yamal-Nenets Autonomous District.

External factors for the Yamal-Nenets Autonomous District also affect the state of its economy. There is a direct correlation between the prices of hydrocarbons on the world market and the economy state of the Yamal-Nenets Autonomous District. The oil and gas sector of the YamalNenets Autonomous District and other sectors, especially budgetary ones, demonstrate the fluctuations in world energy prices. Therefore, the investments and employment are increasing; wages are rising in the budget sector with the growth of oil and gas prices. There are opportunities to upgrade the material and technical base of educational, health, cultural and sports institutions. With a decline in prices in the oil and gas sector conversely, the number of employed and real wages is decreasing, the budgetary sector is shifting to the mode of budgetary economy. Thus, the sustainability of the social and economic development of the Yamal-Nenets Autonomous District as a mono-raw territory is determined by the conjuncture of the world hydrocarbon market. In addition, with a long and sustained rise of gas and oil prices, there are risks of a significant reduction in the level of gas and oil consumption due to the expansion of the alternative energy sources use and increased consumption of energy coals. In this regard, it is strategically important to diversify the sales markets.

The Yamal-Nenets Autonomous District has the centers remoteness for the adoption of state and corporate decisions. In this connection, regional control over the issues of effective development of oil and gas fields is lost. The head offices of the largest subsoil users are located outside the Yamal-Nenets Autonomous District. It leads to the macroeconomic approach to solving production issues instead of the microeconomic one. To consolidate the population in the Yamal-Nenets Autonomous District, it is necessary to improve the population life quality radically [8].

\section{DISCUSSION}

Table I shows the impact of external and internal factors that determine the current state of the district economy.

TABLE I. IMPACT OF EXTERNAL AND INTERNAL FACTORS THAT DETERMINE THE CURRENT STATE OF THE DISTRICT ECONOMY

\begin{tabular}{|c|c|}
\hline \multicolumn{2}{|c|}{$\begin{array}{c}\text { The SWOT - analysis of the Yamal-Nenets Autonomous Region } \\
\text { state }\end{array}$} \\
\hline \multicolumn{2}{|c|}{ External environment } \\
\hline Opportunities & Threats \\
\hline $\begin{array}{l}\text { 1. Demand for the main products } \\
\text { of the Yamal-Nenets Autonomous } \\
\text { District (hydrocarbon raw } \\
\text { materials); } \\
\text { 2. Presence of unique objects of } \\
\text { world importance; } \\
\text { 3. Steady demand for products of } \\
\text { national crafts of indigenous } \\
\text { peoples of the North. }\end{array}$ & $\begin{array}{l}\text { 1. World prices for energy } \\
\text { carriers; } \\
\text { 2. Remoteness of the centers for } \\
\text { the adoption of state and } \\
\text { corporate decisions; } \\
\text { 3. Significant increase in the level } \\
\text { of welfare and quality of life of } \\
\text { the population in the Russian } \\
\text { Federation; } \\
\text { 4. Dominance of transport with } \\
\text { alternative fuels by } 2015\end{array}$ \\
\hline \multicolumn{2}{|c|}{ Internal environment } \\
\hline Strengths & Weaknesses \\
\hline $\begin{array}{l}\text { 1.Valuable and large-scale natural } \\
\text { resources; } \\
\text { 2. Highly qualified personnel; } \\
\text { 3. Immediate proximity to } \\
\text { strategically important facilities } \\
\text { (the Northern Sea Route); } \\
\text { 3. Availability of infrastructure } \\
\text { for transport of recoverable } \\
\text { hydrocarbon feedstocks; } \\
\text { 4. Special biological resources } \\
\text { associated with geographical and } \\
\text { climatic conditions. }\end{array}$ & $\begin{array}{l}\text { 1.Difficulties with the } \\
\text { reproduction of mineral resources; } \\
\text { - mono-raw specialization of the } \\
\text { economy of the Autonomous } \\
\text { district; } \\
\text { 2. Weak development of } \\
\text { infrastructure and supporting } \\
\text { industries; } \\
\text { 3. Negative influence on the } \\
\text { nature and ecology of the district } \\
\text { of industrial objects; } \\
4 \text {. High rates of aging of the } \\
\text { population of the Autonomous } \\
\text { district; } \\
\text { 5. Weak competitiveness of } \\
\text { production due to high costs for } \\
\text { its production (zones of the Far } \\
\text { North, increased labor costs for } \\
\text { employed workers, delivery of } \\
\text { goods, a large length of } \\
\text { infrastructure facilities) }\end{array}$ \\
\hline
\end{tabular}

The small business development level is an important characteristic of the entrepreneurship development and market relations assessment in a certain territory. Small business is typically market based and forms the basis of modern market infrastructure. Small business has a significant impact on the rate of economic growth, the structure and quality of the gross regional product and determines the development scale of the service sector in the economy $[9,10]$.

The starting point for the small business formation in the Yamal-Nenets Autonomous District was the economic transformation in the country in the early nineties of the last century. The dynamics and small business development direction, as in other regions of Russia, were influenced by the industrial infrastructure formed by that time and the life specific way in the Far North.

Considering the "northern" specifics and the monosectoral nature of the region economy, the small and 
medium-sized business sector has been sufficiently developed today. This situation is typical for the regions of the Far North of Russia.

The main directions of the regional economy predetermine the main parameters for the small and medium business development of the Yamal-Nenets Autonomous District for the long term. For the simplicity and convenience of identifying opportunities of the small and medium-sized businesses development, the impact of political, economic, social and technological aspects on the entrepreneurial potential of the Yamal-Nenets Autonomous District is presented in the table II [11].

TABLE II. THE IMPACT OF POLITICAL, ECONOMIC, SOCIAL AND TECHNOLOGICAL ASPECTS ON THE ENTREPRENEURIAL POTENTIAL OF THE YAMAL-NENETS AUTONOMOUS DISTRICT

\begin{tabular}{|c|c|}
\hline \multicolumn{2}{|c|}{$\begin{array}{l}\text { PEST-matrix of entrepreneurial potential of the Yamal- } \\
\text { Nenets Autonomous District }\end{array}$} \\
\hline Politics $\boldsymbol{P}$ & Economics $E$ \\
\hline $\begin{array}{l}\text { I. Stable political } \\
\text { situation; } \\
\text { II. Implementation of } \\
\text { measures taken by the authorities } \\
\text { of the Russian Federation and the } \\
\text { Yamal-Nenets Autonomous } \\
\text { District to develop and expand } \\
\text { services in the areas of medical } \\
\text { services to the population, in the } \\
\text { sphere of tourism, physical } \\
\text { development and sport, } \\
\text { processing spheres of activity } \\
\text { III. }\end{array}$ & $\begin{array}{l}\text { IV. Mono-sectoral nature } \\
\text { of the region's economy; } \\
\text { V. Severance of economic } \\
\text { ties with the central regions of } \\
\text { Russia; } \\
\text { VI. Outflow of passionate } \\
\text { people and finances from the } \\
\text { region in favor of large economic } \\
\text { centers and resettlement sites } \\
\text { when reaching the retirement age. } \\
\text { VII. }\end{array}$ \\
\hline Socium $S$ & Technology $T$ \\
\hline $\begin{array}{l}\text { 1. one of the lowest } \\
\text { unemployment rates in Russia; } \\
2 . \quad \text { The lowest proportion } \\
\text { of the population with incomes } \\
\text { below the subsistence minimum; } \\
3 . \quad \text { The highest level of } \\
\text { employment; } \\
4 \text { H. High need of } \\
\text { organizations and enterprises in } \\
\text { labor resources; } \\
5 . \quad \text { Active migration } \\
\text { processes; } \\
6 . \quad \text { Active involvement in } \\
\text { the sphere of economic relations } \\
\text { of representatives of indigenous } \\
\text { small-numbered peoples of the } \\
\text { north. } \\
7 .\end{array}$ & 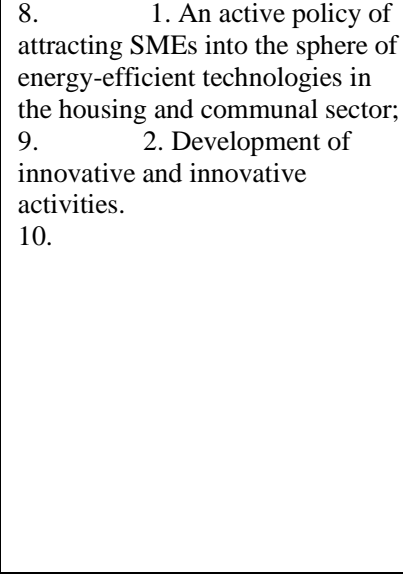 \\
\hline
\end{tabular}

Besides the above factors affected the functioning of small and medium-sized businesses, there are some factors affecting the development of this economy sector. They are the size of the regional market and the level of demand from business entities and individuals, geographical location, resources, a complex transport scheme for the commodity resources delivery in remote hard-to-reach settlements, etc.

In this connection, the Yamal-Nenets Autonomous District, like other regions located in the Far North, is characterized by geographical distance, a break in economic ties with the central regions of Russia, a population and finances outflow from the region in favor of large economic centers and resettlement areas when reaching a pension age [12].

It should be noted that there is one of the lowest unemployment rates in Russia, the lowest share of the population with incomes below the subsistence minimum, the highest level of employment of the population, the high need of organizations and enterprises for labor resources, which is compensated by the recruitment of shift workers from other regions [13].

In addition, active migration processes characterize the district [14]. It is a known fact that a large proportion of the population does not associate their entire life with the Far North. The nature of the "temporality" of residence in the region also influences the small and medium-sized businesses development, despite the fact that the autonomous district retains a considerable potential for its development [15].

\section{RESULTS}

Today the small businesses such as trade (34\% of small enterprises), construction (26\%), real estate operations (14\%) and transport (7\%) have been developed actively.

Stable political environment, high effective demand of the population and measures implementation taken by the authorities of the Russian Federation and the Yamal-Nenets Autonomous District will stimulate the development of medical services, tourism, physical development and sport for the population. An active policy of attracting small business to the energy-efficient technologies in the housing and communal sector is being carried out.

A special role plays the restructuring of large organizations of the fuel and energy complex in favor of "service" companies. Their main part represents high-tech small and medium-sized enterprises. This will contribute to the development of innovative activities, improve the level of production cooperation and prepare training partners. These partners will be able to assume part of the servicing functions, the main production and non-core productions. These processes will provide substantial financial support to small business entities and maintain the employment level of the economically active population of the Yamal-Nenets Autonomous District.

The great potential contains the active involvement of indigenous minorities' representatives of the North in the sphere of economic relations, in the development of reindeer husbandry, processing of venison meat and fish products, handicraft production and their sale for their own needs.

\section{CONCLUSION}

We consider that the implementation of the proposed directions for the entrepreneurial structures development takes into account the factors influencing the activation of entrepreneurship and will allow increasing the degree of economy diversification. It will affect positively the opportunities for achieving the main aim of the social and 
economic development of Yamal-Nenets Autonomous District and improve the life quality of region population.

\section{References}

[1] B.Chernyshov, "Service economy management: the essence and content". The problems of theory and practice management, vol. 1, 2004, pp.107-113.

[2] Y.Nikulina, "The formation of priority directions of social and economic development of the region", World Applied Sciences Journal, 2013, vol. 22, pp. 608-615.

[3] L.L Tonysheva, O.B. Fedorova, "Strategic management of region service economy development", Tyumen: TSOGU, 2013

[4] D.S.White, G.C. Ariguzo and A. Gunasekaran, "The structural components of a knowledge-based economy", International Journal of Business Innovation and Research, vol. 7(4), 2013, pp.504-518.

[5] V.A. Cheymetova, "Theoretical and methodological aspects of choosing the region's development strategy", Economics and Business, vol. 8, 2013, pp.199-203.

[6] A.Zabara, Competitiveness of Krasnodar region economy. European Journal of Economic Studies, vol. 5 (3), 2013, pp.177-180.

[7] O.E.Tokareva, "Theoretical aspects of the analysis of the nature of innovations in the sphere of services", Tyumen State University Herald, vol. 11, 2012, pp.11-16.
[8] E.L. Chizhevskaya and O.B. Fedorova, 'Questions to assess the level of Regional Development'. Oil, Gas and business, vol. 11, 2013, pp.26-29.

[9] L.L. Tonysheva, "Principles development of region economy management in serviceoriented conditions", International theoretical and practical conference, Kiev, 2011, pp. 92-95.

[10] L.L Tonysheva and E.V. Nazmutdinova, "Regional service economics development: foundations and process of strategic management", Life Science Journal, vol. 11(11), 2014, pp.536-539.

[11] N.N. Shilova and N.A. Golubnichiy, "Assessment of the State of Markets Promising for Industrial Enterprises in Tyumen Oblast". Neft, Gaz i Biznes, vol. 2, 2009, pp. 65-68.

[12] I.Yu. Zagoruiko and E.M. Frolovich, "An Investigation into the Development and Optimization of Small Enterprises in Russia amid the Global Downturn", Vestnik Permskogo Universiteta, vol. 3, 2012.

[13] Ye.V. Nazmutdinova, "Methodological Aspects of Determining the Potential of Clusterization of the Region's Economy", Ekonomika i Predprinimatelstvo, vol. 11, 2013, pp. 259-262.

[14] Ye.V. Naznutdinova, "Major Trends in the Development of the Mechanical Engineering Sector in the South of Tyumen Oblast", Ekonomika i Predprinimatelstvo, vol. 2 (43), 2014, pp.96-103.

[15] L.L. Tonysheva., O.B. Fedorova, E.L. Chizhevskaya, "Potentialities of ensuring the resource efficiency of the regional economy". Life Science Journal, vol. 12. , 2015, pp. 558-561. 